\title{
Size-dependent variations in phytoplankton and protozoan community structure across the St. Lawrence River transition region*
}

\author{
Jean-Jacques Frenette, Warwick F. Vincent, Julian J. Dodson, Connie Lovejoy \\ Département de biologie, Université Laval, Sainte-Foy, Québec, Canada G1K 7P4
}

\begin{abstract}
We evaluated 2 contrasting perspectives on the St. Lawrence Estuary maximum turbidity zone (MTZ): the first being that it is a zone of stress and mortality for the plankton community, the second that it is a biologically productive area with a complex, structured food web. Two cruises were undertaken under different hydrologic regimes, one at the end of the spring flood period and the other during mean summer flow conditions. The same pattern of change in community structure of the phytoplankton and protozoa ( 2 to $200 \mu \mathrm{m}$ ) was observed across the saltwater transition in both cruises: there was a shift in the size distribution of taxa towards dominance by larger cells and an increase in the number of taxa (including 'endemic taxa' confined to a specific salinity rangel at the bottom of the transition zone. There was no evidence of a decline in evenness, nor of a shift towards a heterotrophbased food web that would result from the mortality of autotrophs advected into the MTZ. These changes imply a prolonged residence time for the cells in the MTZ and a combination of immigration and emigration pathways that favours larger particles and high taxon diversity. The results are consistent with a 'hydrodynamic entrapment' model. Our observations do not support the earlier views that the St. Lawrence MTZ is a region of unfavourable biological conditions. Conversely, the large average cell size combined with a longer cell-retention time in this region may contribute towards its productivity as a larval fish nursery.
\end{abstract}

KEY WORDS: Estuary · Phytoplankton Protozod - Biovolume - Turbidity · Community

\section{INTRODUCTION}

Hydrodynamic processes such as stratification, turbulent mixing and advection can play a major role in controlling the production, biomass and size distribution of planktonic autotrophs and heterotrophs in freshwater and marine ecosystems (e.g. Reynolds 1984, Cushing 1989, Riegman et al. 1993, Frenette et al. 1994). These physical processes can modify growth rates through their effect on light and nutrient availability and through their influence on the matching between biotic responses such as primary production and zooplankton grazing (Legendre \& Le Fèvre 1989,

\footnotetext{
- Contribution to the programme of CEN (Centre d'études nordiques) and GIROQ (Groupe Interuniversitaire de Recherches Océanographiques du Québec)
}

Vincent 1992). Such processes are likely to play a decisive role across the estuarine maximum turbidity zone (MTZ), where the concentration of suspended material is higher than in upstream and downstream areas. The MTZ is largely the result of hydrodynamic trapping where inorganic and organic particles are retained because they sink into the landward bottom current and because of cyclonic recirculation (see Postma 1967, Moon \& Dunstan 1990). In many estuaries, it is the critical interface for biogeochemical interactions between river water and the sea.

The biological impact of hydrodynamic trapping has been observed at higher trophic levels in the MTZ This region contains high concentrations of estuarine zooplankton species, in particular Eurytemora affinis, Neomysis americana and Mysis stenolepis, that accumulate passively along with suspended particulate matter (Dodson et al. 1989, Laprise \& Dodson 1994). 
The early life-history stages of smelt Osmerus mordax and tomcod Microgadus tomcod are retained in the MTZ through exploitation of the vertical pattern of current speed and direction, and there they feed on the high concentrations of zooplankton in spring and early summer (Laprise \& Dodson 1989a, b, 1990, Dauvin \& Dodson 1990). The combination of constraints imposed by estuarine circulation on the entrapment of planktonic organisms and variability in physico-chemical conditions on the vertical plane is largely responsible for the maintenance of the true estuarine zooplanktonic community that persists at the head of the estuary (Laprise \& Dodson 1993, 1994). In contrast, little is known about lower food chain processes in this region. Simenstad et al. (1990) have drawn attention to the general lack of information about the microbial food web in the estuarine MTZ environment.

There are contradictory accounts about the biological processes which operate in the St. Lawrence MTZ. Cardinal \& Bérard-Therriault (1976) noted the replacement of the freshwater phytoplankton species by marine species within the transition zone. Other authors have observed decreases in chlorophyll a (chl a) concentration and photosynthetic activities in the MTZ and have attributed such effects to possible osmotic stress (Painchaud \& Therriault 1989, Therriault et al. 1990). The St. Lawrence MTZ has been described as a region where the 'phytoplankton community is composed of deteriorating freshwater cells, passively advected from upstream. (Therriault et al. 1990). One zooplankton community structure study revealed a major decrease in abundance and diversity in the MTZ which led Bousfield et al. (1975) to consider this 'zone of mixing of the Upper Estuary to be, in effect, a "graveyard" of bodies of marine and freshwater zooplankton, inexorably carried there and trapped by their swimming behavior and the circulation, and killed by the extreme physical conditions'. A more recent review on estuarine MTZ processes (Kimmerer 1992) reinforces the view of the St. Lawrence MTZ as an area of low to negligible primary production and high zooplankton mortality. However, certain studies on the planktonic animal populations of the St. Lawrence MTZ are at variance with this view. Population data for rainbow smelt and Atlantic tomcod Microgadus tomcod larvae, as well as for several species of macrozooplankton (Dodson et al. 1989, Laprise \& Dodson 1989a), suggest an efficient and productive food web that supports a high biomass of grazers and predators. The seasonal variability in the abundance of microcrustaceans in the MTZ suggests that trophic interactions regulate zooplankton populations and is consistent with an efficient and productive food web (Laprise \& Dodson 1994). Studies on the MTZ elsewhere have begun to challenge the traditional view that primary production is suppressed by salinity, turbidity or other factors in this region (e.g. Moon \& Dunstan 1990, Fichez et al. 1992).

The aim of the present study was to evaluate the 2 conflicting perspectives on the St. Lawrence River MTZ: the first being that it is a zone of stress and mortality, the second being that it is, conversely, a biologically productive area with a complex, structured food web. The former hypothesis implies a substantial loss of plankton taxa and abundance in response to severe osmotic and low-light stress. This would result in a decrease of biomass, diversity and evenness of the community. The latter hypothesis would imply that a diverse community structure is maintained across the MTZ, but with a potential change in species composition. The 'graveyard' hypothesis would imply a decrease in autotrophs due to light limitation and osmotic stress, resulting in a proportional increase in the importance of heterotrophs in the MTZ. Under both scenarios hydrodynamic retention processes would selectively trap the larger, more rapidly sedimenting plankton species. We evaluated these hypotheses by way of 2 cruises under contrasting hydrologic regimes to identify consistent patterns that occurred under a broad spectrum of flows and turbidities. Sampling was conducted during the spring-early summer period when the MTZ acts as a nursery region for the larval smelt and Atlantic tomcod.

\section{MATERIALS AND METHODS}

Study area. In the St. Lawrence Estuary during early spring, the MTZ extends from a tidal marsh region upstream of Cap Brulé to immediately downstream of Ile aux-Coudres (Fig. 1). It is displaced upstream towards Ile d'Orléans during the summer months (Meric 1975, Lucotte \& d'Anglejan 1986). The increased turbidity in this region appears to be primarily the result of hydrodynamic entrapment (d'Anglejan \& Ingram 1984) but is also influenced by lateral exchange with the adjacent salt marshes (Lucotte \& d'Anglejan 1986) and flocculation processes across the salinity gradient (Gobeil et al. 1981).

Sampling. Two sampling cruises were undertaken in 1991, from 10 to 14 May (near the end of the spring flood period) and from 27 June to 1 July (mean summer flow conditions). There was sufficient time between the 2 cruises to allow major changes in the river environment and its plankton communities. During the first cruise 12 stations were sampled in the upper St. Lawrence Estuary along 3 distinct salinity zones: 4 stations in the lower freshwater (but tidal) section ca $30 \mathrm{~km}$ downstream of Québec city (Zone 1), 4 stations in the frontal region of increased turbidity with surface 
salinity in the range 0.7 to $2 \%$; and 4 stations $30 \mathrm{~km}$ further downstream with surface salinities in the range 4 to $8 \%$ (Zone 3). The 4 stations in Zone 1 were within a $2 \mathrm{~km}$ reach of the main channel. The 8 stations in Zones 2 and 3 were also in the main channel and were located within $8 \mathrm{~km}$ reaches. Each zone was sampled twice at low tide and twice at high tide. The second cruise focused on Zones 1 and 2 only to achieve a better temporal resolution of the tidal water masses. A fixed station was occupied in each zone and samples were taken at $4 \mathrm{~h}$ intervals over 3 tidal cycles. A description of the physical and chemical properties of the 3 zones is given in Vincent et al. (1994).

At each sampling time during the 2 cruises, water was obtained from near the surface $(0.5 \mathrm{~m})$ and near the bottom $(17 \mathrm{~m}$, which was at least $3 \mathrm{~m}$ above the sediments) with a 5 I Go-Flow sampling bottle. The phytoplankton and protozoa samples were preserved immediately with a glutaraldehyde-paraformaldehydemixture (Tsuji \& Yanagita 1981) and kept at $4^{\circ} \mathrm{C}$ in the dark until microscopical examination

Community structure. Samples were examined by fluorescence-Nomarski-Utermöhl microscopy using the procedures of Lovejoy et al. (1993). Communities within each sampled zone were characterized by way of demographic parameters: the number of taxa, the community evenness index $(R)$, which describes the relative distribution of cells within each taxon and is used here as a measure of stress, and the Steinhaus similarity index ( $S$ ), which evaluates the similarity between the sampled zones. All indices were calculated from the pooled abundance of all taxa within each zone (as in Legendre \& Legendre 1984).

Size distribution. The biovolume of each taxon was calculated from the microscopic determination of the mean maximal length and width of 20 organisms/ taxon, and the shape was approximated to the nearest morphological volume (e.g. sphere, ovoid, cylinder). Each biovolume/taxon was multiplied by the total number of individuals to obtain the total biovolume per taxon. This biovolume was then partitioned according to the size classes of the cells, which was defined as the maximal linear size of a given taxon and expressed as a biovolume size spectrum. These biovolume distributions were then compared within and between the different zones and time periods with a Maximum Likelihood Chi-squared analysis $\left(G^{2}\right)$.

Taxon functional categories. The enumerated taxa were initially grouped into 7 broad categories based on their taxonomic affinities: phytoflagellates (Group 1), colorless flagellates (Group 2), ciliates (Group 3), rhizopods (Group 4), cyanobacteria (Group 5), diatoms (Group 6) and the remaining autotrophs (Group 7). Two functional categories were further obtained from these groups: the autotrophs (chl a containing cells), which represented Groups 1, 5, 6 and 7, and the heterotrophs (absence of chl a), which included Groups 2, 3 and 4 . For each category, the total number of individuals and the total biovolume of organisms was calculated from the summation of all the included taxa. For each depth, the total number of individuals by category was then calculated at each station and zone. The biovolumes for the 7 groups were summed to give the total plankton volume.

\section{RESULTS}

\section{Spatial variation}

Total community. The dominant taxa in each of the 7 groups of phytoplankton and protozoa are given in Table 1 . The community structure varied with depth and zone across the transition region. During Cruise 1 , evenness increased downstream with increased domi- 
Table 1. Major taxon composition for each of the 7 functional categories sampled in the St. Lawrence transition region during May and June-July 1991. Autotrophs include Groups 1, 5,6 and 7. Heterotrophs include Groups 2, 3 and 4

\begin{tabular}{|c|c|c|c|c|}
\hline Group & Category & No. of taxa & Major taxa & Range of composition $(\%)$ \\
\hline 1 & $\begin{array}{l}\text { Flagellates with } \\
\text { chloroplasts }\end{array}$ & 32 & $\begin{array}{l}\text { Cryptomonas cf. marssonii } \\
\text { Unidentified flagellate } \\
\text { Mallomonas sp. cf. allorgei } \\
\text { Dinobryon sp. } \\
\text { Ochromonas sp. } \\
\text { Emiliania sp. }\end{array}$ & $\begin{array}{l}38-48 \\
10-17 \\
29-36 \\
11-17 \\
11-17 \\
11-19\end{array}$ \\
\hline 2 & $\begin{array}{l}\text { Flagellates } \\
\text { without } \\
\text { chloroplasts }\end{array}$ & 26 & $\begin{array}{l}\text { Spumella sp. B } \\
\text { Chilomonas sp. } \\
\text { Epibiont A on Melosira } \\
\text { Spumella sp. A } \\
\text { Peltomonas sp. }\end{array}$ & $\begin{array}{r}24-56 \\
14-38 \\
18-22 \\
8-22 \\
9-17\end{array}$ \\
\hline 3 & Ciliates & 12 & $\begin{array}{l}\text { Tintinnopsis cf. minuta } \\
\text { Tintinnopsis cf. subacuta } \\
\text { Tintinnidium sp. C } \\
\text { Strombidium sp. B }\end{array}$ & $\begin{array}{l}35-100 \\
31-83 \\
22-38 \\
17-42\end{array}$ \\
\hline 4 & Rhizopods & 5 & $\begin{array}{l}\text { Flabellula demetica } \\
\text { Oxnerella or Chlamydaster } \\
\text { Paulinella sp. }\end{array}$ & $\begin{array}{l}61-100 \\
30-100 \\
27-54\end{array}$ \\
\hline 5 & $\begin{array}{l}\text { Phytoplankton } \\
\text { subgroup A: } \\
\text { cyanobacteria }\end{array}$ & 7 & $\begin{array}{l}\text { Chroococcus cf. dispersus } \\
\text { Synechocystis sp. }\end{array}$ & $\begin{array}{l}39-95 \\
20-56\end{array}$ \\
\hline 6 & $\begin{array}{l}\text { Phytoplankton } \\
\text { subgroup B: } \\
\text { diatoms }\end{array}$ & 23 & $\begin{array}{l}\text { Melosira granulata sp. } \\
\text { Thalassiosira cf. nordenskiöldii } \\
\text { Cyclotella sp. } \\
\text { Diatomella sp. A } \\
\text { Diatomella sp. B }\end{array}$ & $\begin{array}{l}19-72 \\
17-70 \\
14-23 \\
10-14 \\
10-13\end{array}$ \\
\hline 7 & $\begin{array}{l}\text { Phytoplankton } \\
\text { subgroup C: } \\
\text { remaining taxa }\end{array}$ & 38 & $\begin{array}{l}\text { Chlorella sp. A } \\
\text { Chlorella sp. B } \\
\text { Selenastrum sp. } \\
\text { Chlorella ellipsoidea } \\
\text { Monoraphidium sp. A }\end{array}$ & $\begin{array}{l}16-23 \\
12-25 \\
21-22 \\
11-13 \\
10-13\end{array}$ \\
\hline
\end{tabular}

nance by a larger number of taxa from Zone 1 to Zone 3 at the surface and from Zone 1 to Zone 2 at the bottom (Table 2). At the transition Zone 2, the total num-

Table 2. Species number $(\mathrm{n})$, evenness $(R)$ and Steinhaus similarity index $(S)$ for the phytoplankton and the protozoan community in each zone of the St. Lawrence River transition region. Each zone was sampled 4 times during Cruise 1 and 13 times during Cruise 2 (except surface waters of Zone 2 that were sampled 12 times)

\begin{tabular}{|c|c|c|c|c|c|}
\hline & \multicolumn{3}{|c|}{ Cruise 1} & \multicolumn{2}{|c|}{ Cruise 2} \\
\hline & Zone 1 & Zone 2 & Zone 3 & Zone 1 & Zone 2 \\
\hline \multicolumn{6}{|c|}{ Surface } \\
\hline $\mathrm{n}$ & 66 & 55 & 61 & 88 & 75 \\
\hline$R$ & 0.80 & 0.85 & 0.90 & 0.75 & 0.81 \\
\hline$S$ & \multicolumn{3}{|c|}{0.40} & \multicolumn{2}{|c|}{0.43} \\
\hline \multicolumn{6}{|c|}{ Bottom } \\
\hline $\mathrm{n}$ & 59 & 73 & 40 & 90 & 93 \\
\hline$R$ & 0.78 & 0.88 & 0.90 & 0.73 & 0.85 \\
\hline$S$ & \multicolumn{2}{|c|}{0.32} & & \multicolumn{2}{|c|}{0.39} \\
\hline
\end{tabular}

ber of taxa declined at the surface and increased at the bottom when compared with Zones 1 and 3. During the second cruise similar trends were observed between the freshwater Zone 1 and transition Zone 2 (Table 2). The highest number of taxa (total) was recorded at the bottom of Zone 2 during both cruises

There was a longitudinal change in taxon composition at each depth (Table 2). Calculations of the Steinhaus similarity index (based on common taxa only) across zones for the surface communities show a closer relationship between Zones 2 and $3(0.51)$ in comparison to Zones 2 and $1(0.40)$. The same analysis for the bottom samples indicate equal similarities between the transition Zone 2 and either Zone $1(0.32)$ or Zone 3 (0.34).

Many of the taxa observed within this study were found only within 1 of the 3 zones (Fig. 2). The highest percentage of these 'endemic taxa' (by which we mean taxa that were exclusively recorded in 1 zone) was at the bottom of transition Zone $2(40 \%)$. Common taxa amongst the 3 zones were more abundant at the sur- 
face $(26 \%)$ than at the bottom $(18 \%)$, which agreed with the similarity index values. During the second cruise, a high number of 'endemic taxa' were also observed at the surface of Zone 1 (36\%) (Fig. 3)

There was an increase from Zone 1 to Zone 3 in the vertical partitioning of taxa. This effect can be seen by the downstream gradient in the partitioning index as shown in Fig. 4. This trend is associated with the gradient in salinity, but also stratification: Zone 1 was well mixed and Zones 2 and 3 showed increasing stratification (details in Bertrand \& Vincent 1994). Similar results were observed during Cruise 2. During both cruises, a much larger number of taxa in transition Zone 2 were found exclusively at the bottom of the water column ( $45 \%$ of all Zone 2 taxa in Cruise 1, 38\% in Cruise 2 ) than at the surface ( $27 \%$ of all Zone 2 taxa in Cruise 1, 23\% in Cruise 2).

Autotrophs and heterotrophs. There were minor changes in community structure of autotrophs and heterotrophs across the zones in each cruise (Table 3). During both cruises, the number of autotrophic taxa was 3 to 4 times greater than the heterotrophic taxa, and their relative distribution varied with depth across
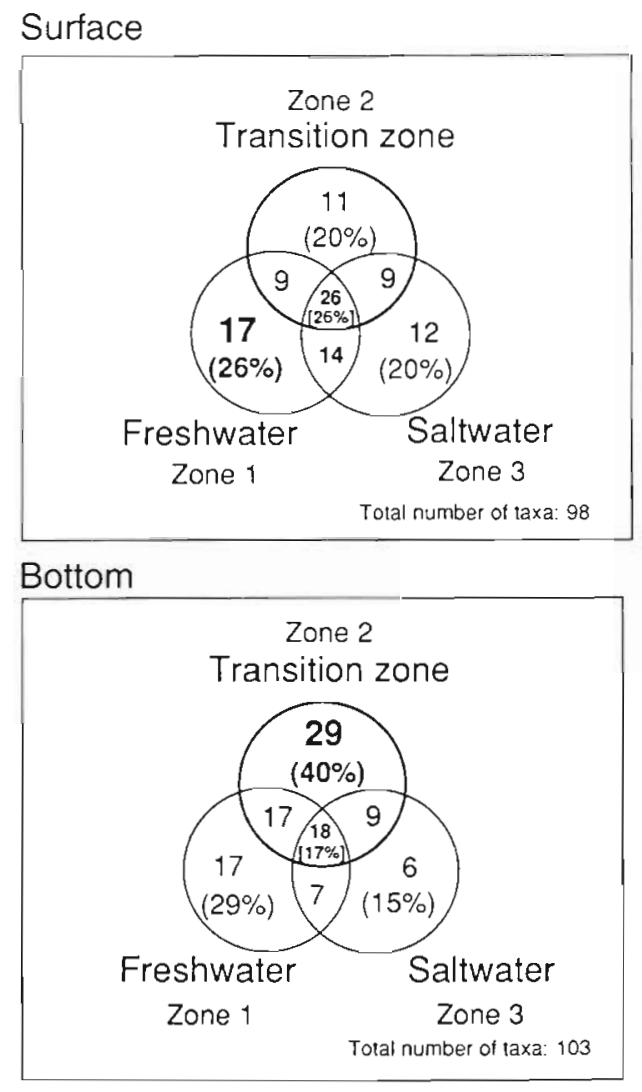

Fig. 2. Number of phytoplankton and protozoa taxa sampled within each zone across the St. Lawrence River transition region during Cruise 1 (10 to 14 May 1991)
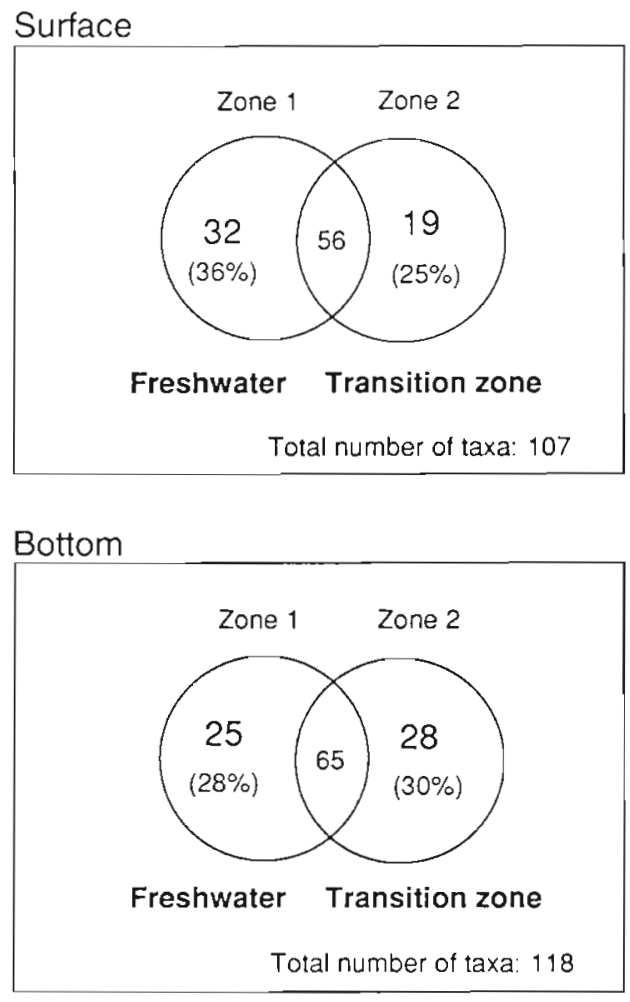

Fig. 3. Number of phytoplankton and protozoa taxa sampled within each zone across the St. Lawrence River transition region during Cruise 2 (27 June to 1 July 1991)

\section{Total community \\ Freshwater Transition Saltwater}

Cruise 1

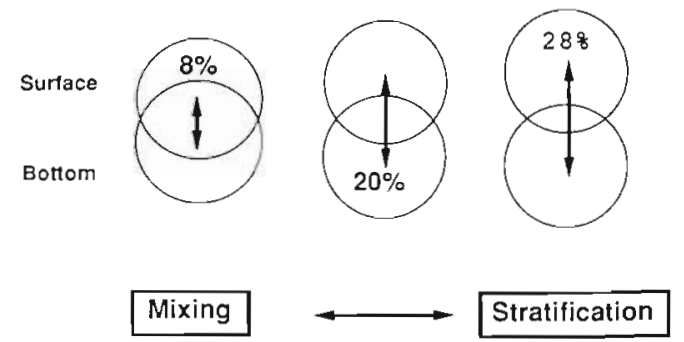

Cruise 2

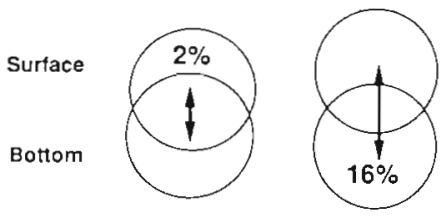

Fig. 4. Vertical partitioning index [(|no. of 'endemic' taxa at the surface - no. of 'endemic' taxa at the bottom//total no. of taxa) $\times 100$ f for the phytoplankton and protozoa communities sampled during Cruises 1 and 2. The values are placed in the circle corresponding to the depth of greater number of endemic species 
Table 3. Species number ( $\Omega$ ), evenness $(R)$ and Steinhaus simllarity index $(S)$ for the autotrophs and the heterotrophs in each zone of the St. Lawrence River transition region. Each zone was sampled 4 times during Cruise 1 and 13 times during Cruise 2 (except surface waters of Zone 2 that were sampled 12 times)

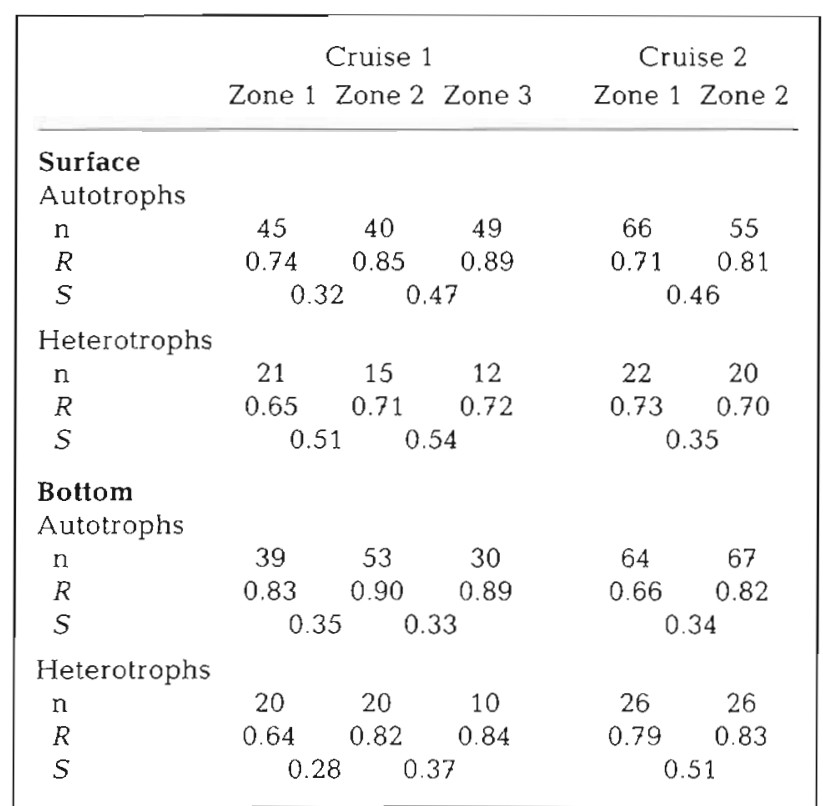

the zones. Contrary to the hypothesis that the MTZ is a stress and mortality zone, there was a slight increase in diversity and evenness of both groups and there was no evidence of a differential loss of autotrophic taxa at the expense of heterotrophs.

\section{Demographic parameters}

Abundance. In both cruises (in Zones 1 and 2) the numerical dominants were heterotrophic flagellates (Group 2) which contributed between 25 and $47 \%$ of total cell counts (Fig. 5). In Zone 3, autotrophic and heterotrophic flagellates codominated. Diatoms rose in abundance and relative importance in the second cruise.

During Cruise 1, there was a sharp decrease in abundance of total autotrophs as well as heterotrophs between the freshwater Zone 1 and the transition Zone 2 at the surface $(2.6 \times)$ and at the bottom $(2 \times)$ of the water column (Table 4). The number of cells decreased slightly $(1.1$ to $1.5 x)$ thereafter in saltwater Zone 3. Similar results were found in Cruise 2, with a higher abundance of both categories of cells in Zone 1 than in Zone 2. The concentration of autotrophs increased during the second cruise, resulting in a proportional reduction in the importance of heterotrophs. There was no evidence in either cruise of a shift towards heterotrophic dominance across the MTZ.

Total biovolume. In both cruises, diatoms were the major contributors to total biovolume with a relative contribution varying between 33 and $70 \%$ (Fig. 6). Group 7 taxa also contributed substantially to total biovolume during Cruise 1 in Zones 1 and 2. Diatoms rose in biovolume and relative importance during Cruise 2.

During Cruise 1, the total biovolume of autotrophs remained unchanged between Zones 1 and 2 at both the surface and the bottom of the water column (Table 5). Heterotrophs decreased in biovolume
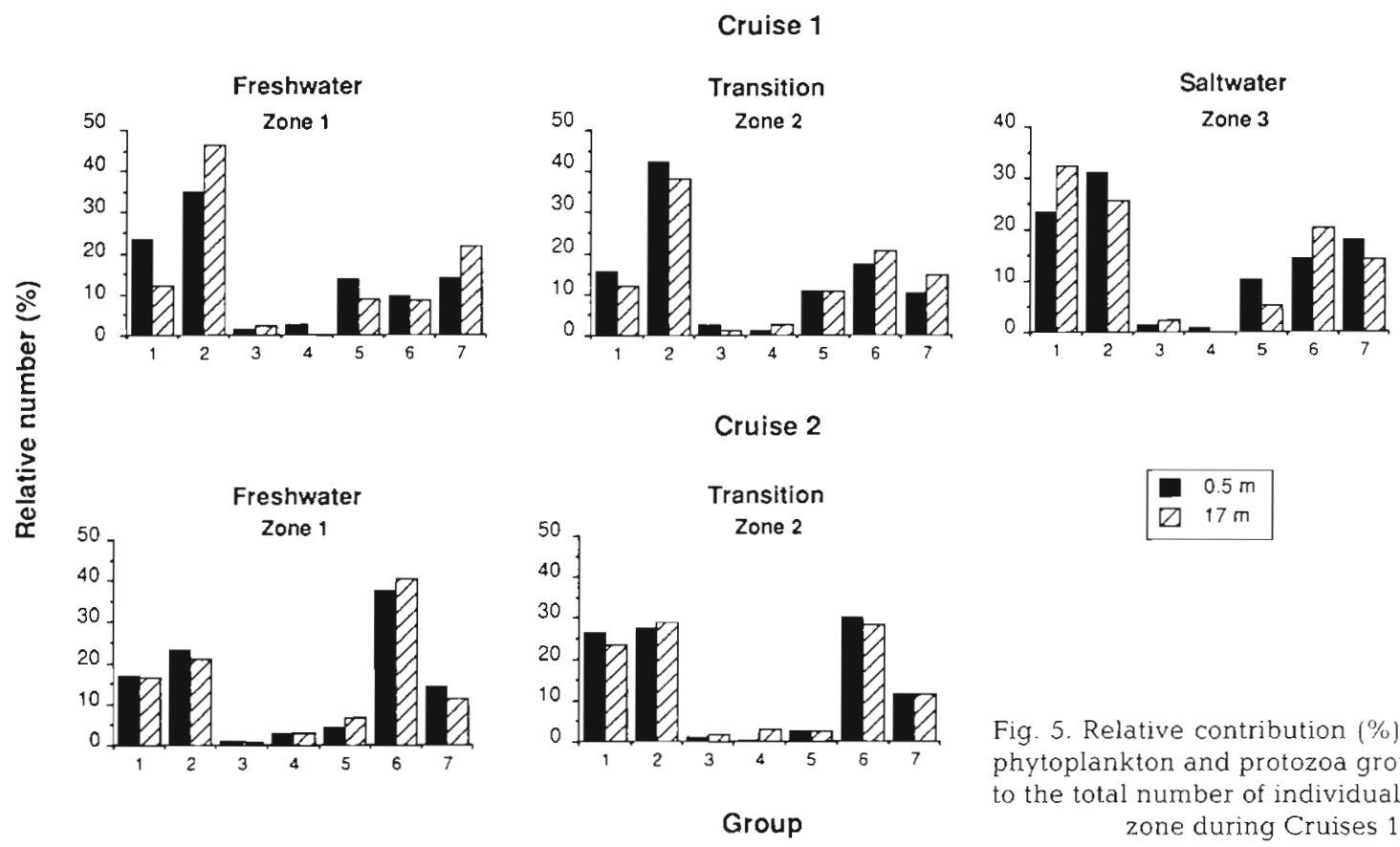

Fig. 5. Relative contribution (\%) of each of the 7 phytoplankton and protozoa groups (see Table 1) to the total number of individuals in each salinity zone during Cruises 1 and 2 


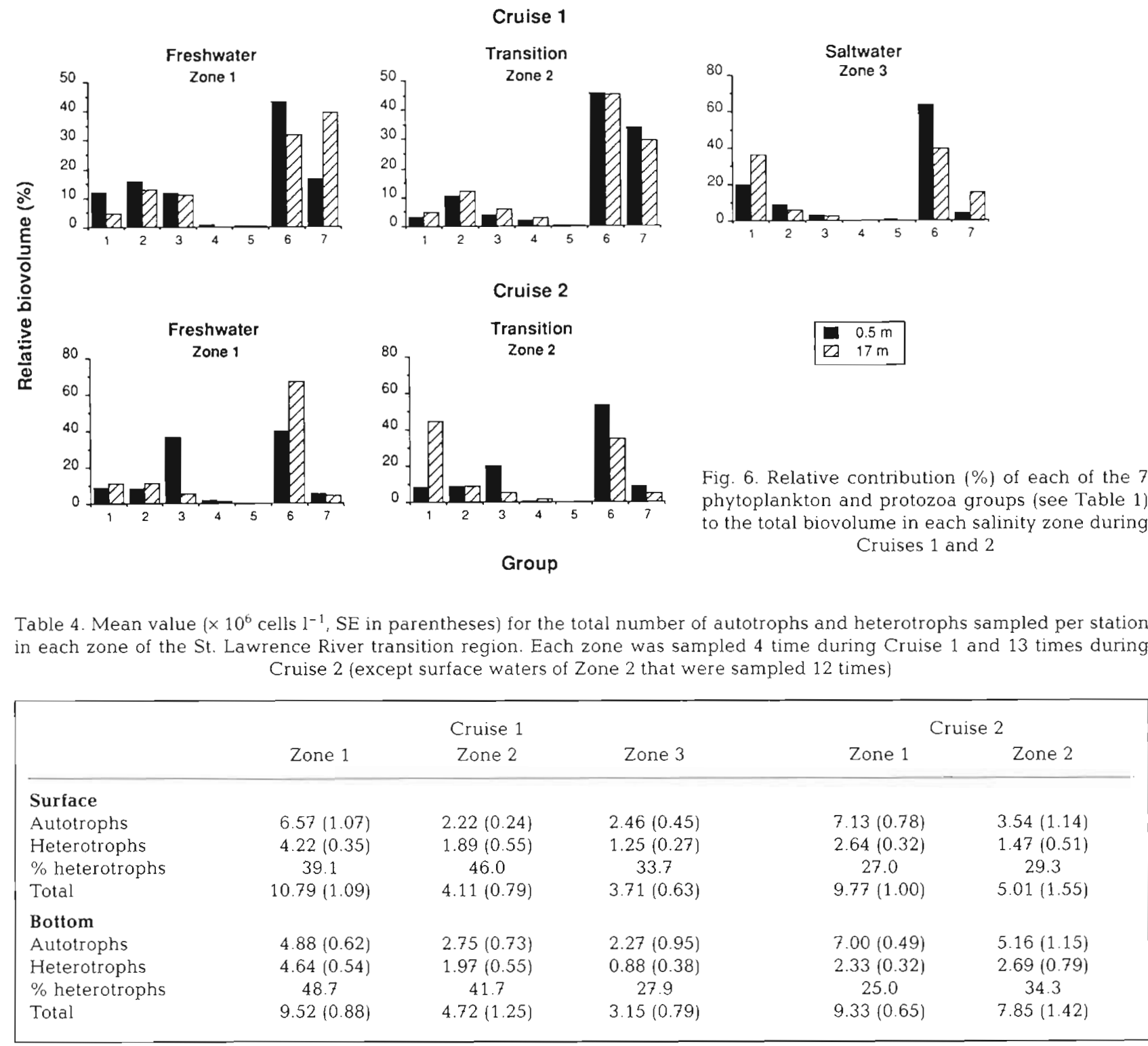

Table 5. Mean value ( $\times 10^{6} \mathrm{\mu m}^{3} \mathrm{l}^{-1}$, SE in parentheses) for the total cell volume of autotrophs and heterotrophs sampled per station in each zone of the St. Lawrence River transition region. Each zone was sampled 4 times during Cruise 1 and 13 times during Cruise 2 (except surface waters of Zone 2 that were sampled 12 times)

\begin{tabular}{|c|c|c|c|c|c|}
\hline & \multicolumn{3}{|c|}{ Cruise 1} & \multicolumn{2}{|c|}{ Cruise 2} \\
\hline & Zone 1 & Zone 2 & Zone 3 & Zone 1 & Zone 2 \\
\hline \multicolumn{6}{|l|}{ Surface } \\
\hline Autotrophs & $1388(312.7)$ & $1401(594.9)$ & $905.3(450.1)$ & $1400.1(170.3)$ & $1204.8(519.4)$ \\
\hline Heterotrophs & $540.8(155.6)$ & $282.7(54.7)$ & $120.9(49.9)$ & $1191.2(834)$ & $503.7(281.2)$ \\
\hline$\%$ heterotrophs & 28.0 & 16.8 & 11.8 & 46.0 & 29.5 \\
\hline Total & $1928.8(356)$ & $1683.7(579)$ & $1026.2(500)$ & $2591.3(900)$ & $1708.5(544)$ \\
\hline \multicolumn{6}{|l|}{ Bottom } \\
\hline Autotrophs & $1630.8(312.8)$ & $1541.4(539.7)$ & $1376.7(423.1)$ & $1438.8(145.0)$ & 4096.7 (2139.5) \\
\hline Heterotrophs & $510.2(62.4)$ & $397.2(134.4)$ & $130.4(84.9)$ & $312.0(63.9)$ & $752.4(139.2)$ \\
\hline$\%$ heterotrophs & 23.8 & 20.5 & 8.7 & 17.8 & 9.3 \\
\hline Total & $2141(364)$ & $1938.6(645)$ & $1507.1(394)$ & $1750.8(190)$ & $4849.1(2160)$ \\
\hline
\end{tabular}


Table 6. Mean biovolume $\left(\mu \mathrm{m}^{3} \mathrm{~L}^{-1}\right)$ of phototrophs and heterotrophs in each zone of the St. Lawrence River transition region

\begin{tabular}{|lccrcc|}
\hline & \multicolumn{3}{c}{ Cruise 1 } & \multicolumn{2}{c|}{ Cruise 2 } \\
& Zone 1 & Zone 2 & Zone 3 & Zone 1 & Zone 2 \\
\hline Surface & & & & & \\
Autotrophs & 211.3 & 629.5 & 368.2 & 196.3 & 340.7 \\
Heterotrophs & 128.1 & 149.9 & 96.6 & 452 & 343.2 \\
Total & 178.7 & 409.6 & 276.6 & 265.2 & 341.4 \\
Bottom & & & & & \\
Autotrophs & 334.2 & 559.7 & 607.8 & 205.6 & 794.7 \\
Heterotrophs & 110.1 & 201.1 & 148.9 & 133.9 & 279.9 \\
Total & 225 & 409.9 & 479.8 & 187.7 & 618.2 \\
\hline
\end{tabular}

between Zone 1 and Zone 3 at both depths resulting in a proportional reduction in the importance of heterotrophs. Such a decrease in the representation of heterotrophs was also observed at both depths of Zone 2 during Cruise 2. Maximum biovolume was found at the bottom of Zone 2 for both categories of cells. There was no evidence in either cruise of a shift towards heterotrophic dominance in total biovolume across the MTZ.

Mean biovolume. During Cruise 1 , the average size of autotroph and heterotroph taxa increased between Zones 1 and 2 for the surface and the bottom samples (Table 6). In saltwater Zone 3, the size of the autotrophic cells decreased at the surface and increased at the bottom. Similar results were observed in Cruise 2 with a larger size of the autotrophs in Zone 2 than Zone 1. For the total community, there was a substantial increase $(30$ to $230 \%$ ) in mean cell volume across the transition from Zone 1 to Zone 2 in both cruises.
Biovolume size spectrum. The biovolume size spectra of the phytoplankton and protozoan communities (Figs. $7 \& 8$ ) were significantly different [Maximum Likelihood Chi-squared analysis $\left.\left(G^{2}\right), \mathrm{p}<0.01\right]$ between zones in both cruises. During both sampling periods, there was a shift of cell biovolume into larger size classes between Zones 1 and 2 for the total plankton community. During Cruise 1 , the proportion of biovolume present in the $>20 \mu \mathrm{m}$ fraction increased from 51 and $58 \%$ in Zone 1 to 72 and $64 \%$ in Zone 2 for the surface and bottom samples respectively. The $>20 \mu \mathrm{m}$ fraction reached $68 \%$ of total biovolume at the bottom of saltwater Zone 3. Cells larger than $150 \mu \mathrm{m}$ were poorly represented in saltwater zone 3. During Cruise 2, the shift into larger size classes was more pronounced, with the proportion of cells $>20 \mu \mathrm{m}$ increasing from 50 and $22 \%$ to 64 and $82 \%$ for surface and bottom samples respectively.

\section{DISCUSSION}

\section{Impact of hydrodynamic trapping on community structure}

The pattern of change in the phytoplankton and protozoa communities across the MTZ showed several characteristics which are consistent with estuarine recirculation and hydrodynamic trapping. These effects can be summarized by the schematic model given in Fig. 9. This conceptual model incorporates the following changes in community structure that we observed during the 2 cruises: (1) the shift (skewness) in the size distribution of taxa towards dominance by

\section{Cruise 1}

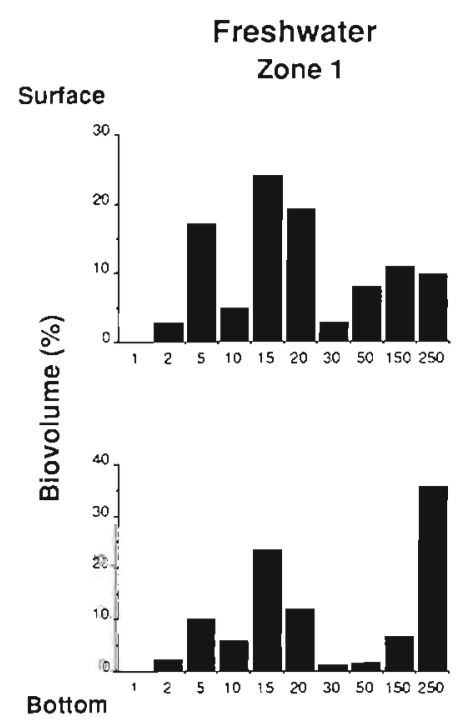

Freshwater

urface
Transition Zone 2
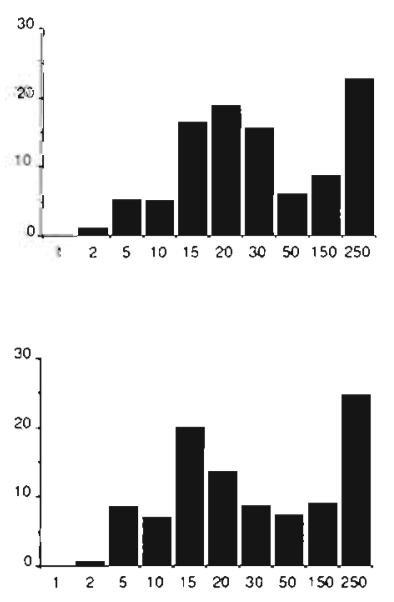

Size $(\mu \mathrm{m})$

\section{Saltwater \\ Zone 3}
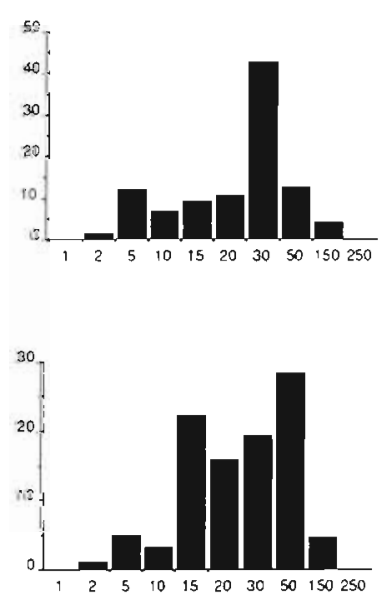

Fig. 7. Biovolume size spectra for the phytoplankton and protozoa communities at the surface and the bottom of each salinity zone during Cruise 1 


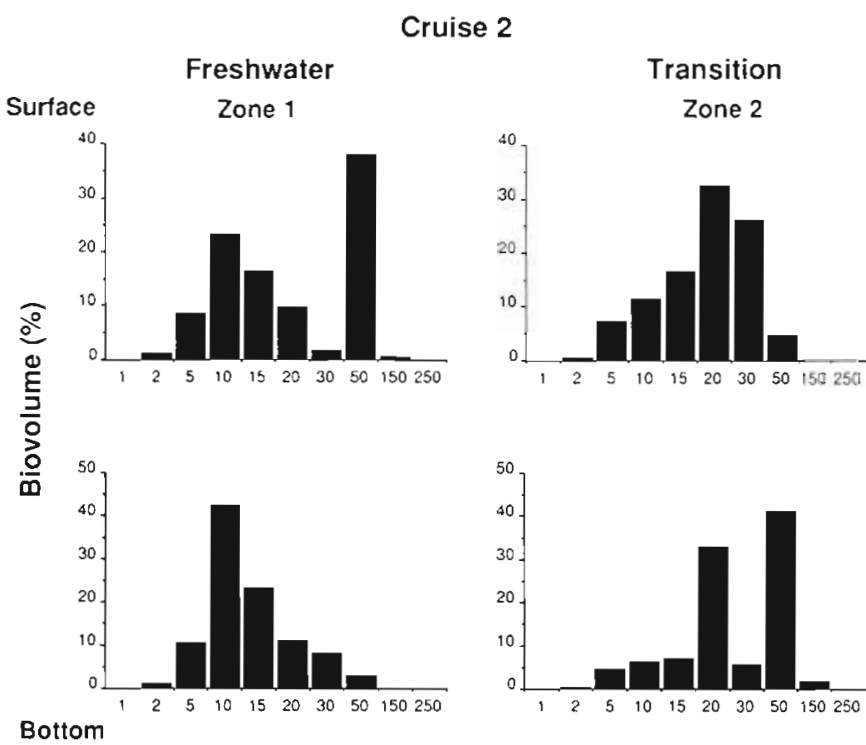

Size $(\mu \mathrm{m})$

Fig. 8. Biovolume size spectra for the phytoplankton and protozoa communities at the surface and the bottom of each salinity zone during Cruise 2

larger cells in the St. Lawrence transition Zone 2, (2) the large increase in number of taxa (including 'endemic taxa') at the bottom of Zone 2, and (3) the non-differential effect on heterotrophs which remained at more or less the same proportional abundance across the transition zone. This model implies a prolonged residence time for the cells in Zone 2 and a combination of immigration and emigration pathways that differentially favours larger size particles and a high taxon diversity.

Larger mean size. The increase in size of the phytoplankton and the protozoan community in transition Zone 2 can be explained by the sedimentation-resuspension circulation pattern which characterizes this zone. In this situation, dense particles sink into the high density upstream bottom current to be subsequently resuspended at the surface near the landward extent in the salt intrusion of Zone 2 (d'Anglejan \& Ingram 1984, Lucotte \& d'Anglejan 1986). This process is consistent with the decrease in cell concentration yet constant biovolume (mean = biovolume/density) observed across the Zone 1/Zone 2 transition. Such an effect would result from a faster flushing of the smaller size particles out of the zone, because of their lower sinking rate (Stoke's law), and faster sedimentation of larger particles which then accumulate through recirculation and resuspension.

High number of taxa. All measurements of plankton community structure are limited by sampling regime, enumeration methodology and taxonomic expertise. In this study we used a high resolution method that gave improved recognition of species, particularly aplastidic protozoan species (Lovejoy et al. 1993). We undersampled the larger protozoan taxa, particularly rhizopods and ciliates, although our estimates lie within the range obtained in other nutrient-rich marine environments (Andersen \& Sorensen 1986, Painting et al. 1992, Rogerson \& Laybourn-Parry 1992a). Comparisons of number of taxa using different methods and taxonomic criteria should be made with caution, and we therefore limit our discussion of these indices to comparisons within the context of our own study using the same methodology.

The diverse community encountered at the bottom of transition Zone 2 is likely to be a product of the additive sedimention and resuspension processes which ultimately concentrate the organisms at the bottom. This higher taxonomic richness may reflect the immigration of taxa from a greater diversity of habitats. Benthic, epibenthic and pelagic organisms may all contribute to the taxon assemblage via the sedimentation-recirculation process which prevails in this section of the estuary. Further evidence of such effects is given by the presence of sediment-related heterotrophic rhizopods (Rogerson \& Laybourn-Parry 1992b) in the transition zone. This supports earlier observations that sediment resuspension, particularly near the head of the estuary, is the main process contributing suspended particulate matter to the turbidity maximum (Silverberg \& Sundby 1979).

Proportion of heterotrophs. Autotrophic taxa (Groups 1, 5, 6 and 7) remained important throughout

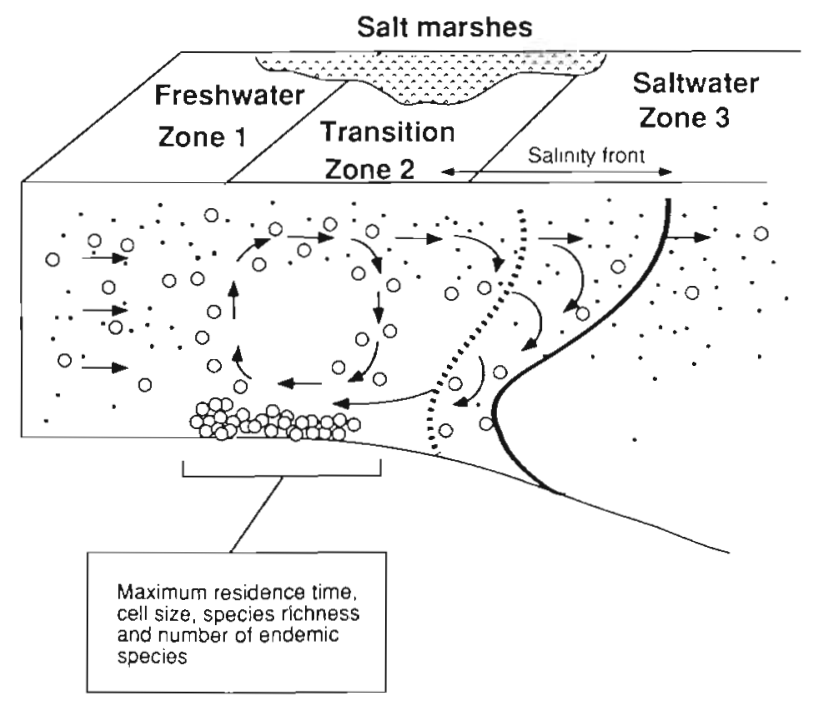

Fig. 9. Conceptual model of the entrapment zone showing the pattern of change in phytoplankton and protozoa communities across the St. Lawrence Maximum Turbidity Zone 
the St. Lawrence upper estuary and there was no evidence of a shift towards a heterotroph-based food web across the MTZ. Our observations suggest that the population dynamics of cells in the transition zone is controlled by hydrodynamic processes rather than by shifts in the relative importance of autotrophy versus heterotrophy. The high densities of macrozooplankton populations in this zone (Laprise \& Dodson 1993) are likely to give rise to a strong grazing and predation pressure on the communities described here. As with hydrodynamic entrapment, there may be some influence of these biological processes on size distribution (Riegman et al. 1993). However, this would not be likely to have a differential effect on heterotrophs versus autotrophs.

Residence time. The residence time of suspended particulate matter exceeds residence time of water in the transition zone (d'Anglejan \& Ingram 1984, Painchaud et al. 1990). The MTZ assemblage therefore represents a time integral of upstream and downstream communities that have been further subject to differential production and loss processes within the transition zone. The low number of common taxa found between the transition Zone 2 and the adjacent zones indicates an immigration and integration period greater than the sampling time (i.e. $>1 \mathrm{wk}$ ). This implies that a given taxon may originate from a past intrusion and accumulation and/or is the result of in situ succession. Cushing et al. (1993) have similarly pointed out that riverine pools of fine particulate organic matter can originate from great distances for subsequent utilization in the river or for export to estuaries.

The high percentage $(\geq 40 \%)$ of 'endemic' autotrophic and heterotrophic taxa at the bottom of Zone 2 strongly suggests an efficient retention mechanism which concentrates particles over a given integration time scale. However, the lack of similarity (very low number of common taxa) between the 2 cruises indicates that at a time scale of $6 \mathrm{wk}$ or less there was major successional change in all zones.

Cell immigration pathways. Lateral as well as continuous longitudinal transport is likely to introduce 'new' species into the MTZ. The highly productive salt marshes (see Lucotte \& d'Anglejan 1986) on both sides, but particulariy the north shore of the estuary, may serve as important reservoirs of taxa transported into the MTZ during tidal fluctuations. The peak biomass found in the turbidity maximum of northem San Francisco Bay has been shown to be largely derived from the lateral input of phytoplankton from extensive, highly productive shoals (discussed in Schuchardt \& Schirmer 1991). Similarly, in the Orinoco (Lewis 1988) and Hudson rivers (Cole et al. 1992), the increase in biomass may be maintained by occasional influxes of phytoplankton from shallow areas into deeper zones.

\section{Trophodynamics across the MTZ}

Our results do not support the earlier view that the St. Lawrence MTZ is a region of unfavourable biological conditions. Contrary to the 'zone of stress' hypothesis, we did not observe any decline in evenness that would mark the increased dominance by a small number of tolerant genotypes. There was no decline in taxon number, nor any evidence of a shift towards heterotroph dominance that would result from the mortality of autotrophs advected into the MTZ.

There was a substantial decline in the concentration of heterotrophs and autotrophs across the Zone 1/ Zone 2 transition during both cruises. Although this reduction in population size could be the result of increased losses due to salinity and nutrient stress, it could equally result from zooplankton grazing. The former explanation seems unlikely given our observations on community structure. It is also incompatible with recent primary productivity studies which show no change in the photosynthesis: chl a ratio across the transition zone (Bertrand \& Vincent 1994, Vincent et al. 1994). Furthermore, there is evidence of increased rather than decreased nitrogen and phosphorus within the MTZ relative to upstream concentrations (Bertrand \& Vincent 1994). Grazing pressure by the large standing stocks of zooplankton is the more likely explanation of the observed drop in cell concentration across the St. Lawrence MTZ.

Our results for the nano- and microplankton are consistent with recent observations on the MTZ macroplankton. The region contains high population densities of larval fish (see Dodson et al. 1989, Laprise \& Dodson 1989a). The major food items of these fish include Eurytemora affinis and Bosmina longirostris, which are also found in abundance (Dauvin \& Dodson 1990). These zooplankton are potential grazers of the phytoplankton and protozoa. The nano- and microplankton observed during our study included heterotrophic protozoa (colorless flagellates, ciliates and rhizopods) and autotrophs (e.g. diatoms). Ciliates were dominated by small-sized species, typically less than $50 \mu \mathrm{m}$, such as Tintinnopsis cf. minuta, Tintinnopsis cf. subacuta and Strombidium sp. Algal heterotrophy would be advantageous in this turbid, low-light environment (e.g. Burkholder 1992). The pigmented flagellates that we recorded are likely to include mixotrophic species (Cavalier-Smith 1993). Our analysis shows that there are substantial changes in community structure across the region. There are also vertical differences in the nano- and microplankton (this study), as well as macroplankton (Dodson et al. 1989) communities down the water column; this vertical structure becomes increasingly pronounced in the physically stratified waters further down the estuary (Fig. 4). The 
overall trophodynamic picture of the MTZ is thus of a region containing a complex, productive food web that includes microbial as well as large-celled constituents at its base.

It is possible that the disparity between the perspectives developed within the present study and previous interpretations is primarily due to differences in sampling regime. Bousfield et al. (1975) sampled primarily copepods and failed to establish the trophic link between mesozooplankton and larval fish. The sampling scale of Painchaud \& Therriault (1989) prevented them from seeing many of the community shifts observed in the present study. They situated the decline in photosynthesis per unit of biomass in waters greater than $10 \%$. However, these salinities fall outside the transition zone as defined by the region of maximum turbidity. In fact, inspection of their data indicates no decline in the production to biomass ratio in the region with salinities equivalent to our transition Zone 2. Similarly the decline in cell concentration of phytoplankton reported by Cardinal \& Bérard-Therriault (1975) was downstream of the turbidity maximum as defined by d'Anglejan \& Ingram (1984)

Although there was a decline in cell numbers (this study) and chl a (Vincent et al. 1994) across the MTZ we found no major drop in total phytoplankton and protozoa biovolume because of the shift toward larger cells. These larger particles could potentially favour a short food chain, and thus a more efficient transfer of carbon and energy to higher trophic levels (cf. Cushing 1989, Legendre \& Le Fèvre 1989). In this way the sizedifferential effects of hydrodynamic trapping, combined with the effects of prolonged retention time, may contribute towards the productivity of this region as a larval fish nursery.

Acknowledgements. This research was supported by grants from the Conseil de recherches en sciences naturelles et de génie du Canada and from Pèches et Océans, Canada. We thank Normand Bertrand, Maude Lecourt, Caroline Berger, Michel Boulé and Marie-Hélène Michaud for assistance at various stages in this project and the master and crew of RV 'Alcide Horth' We also thank Jean Painchaud, Université Laval, and Serge Dalot from the Observatoire océanologique de Villefranche-sur-Mer (France) for helpful discussions.

\section{LITERATURE CITED}

Anderson, P., Sorensen, H. M. (1986). Population dynamics and trophic coupling of pelagic microorganisms in eutrophic coastal waters. Mar. Ecol. Prog. Ser. 33: 99-109

Bertrand, N., Vincent, W. F. (1994) Structure and dynamics of photosynthetic picoplankton across the saltwater transition zone of the St. Lawrence River Can. J. Fish. Aquat. Sci. 51: 161-171

Bousfield, E. L., Filteau, G., O'Neil, M., Gentes, P. (1975). Population dynamics of zooplankton in the middle St.
Lawrence Estuary. In: Cronin, L. E. (ed.) Estuarine Research, Vol. 1. Academic Press, New York, p. 325-341

Burkholder, J. M. (1992). Phytoplankton and episodic suspended sediment loading: phosphate partitioning and mechanisms for survival. Limnol. Oceanogr 37: 974-988

Cardinal, A., Bérard-Therriault, L. (1976). Le phytoplancton de l'Estuaire moyen du Saint-Laurent en amont de l'Ileaux-Coudres (Québec). Int. Rev. ges. Hydrobiol. 61: $639-648$

Cavalier-Smith, T. (1993). Kingdom protozoa and its 18 phyla. Microbiol. Rev. 57: 953-994

Cole, J. J., Caraco, N. F., Peierls, B. L. (1992). Can phytoplankton maintain a positive carbon balance in a turbid, freshwater, tidal estuary? Limnol. Oceanogr. 37: $1608-1617$

Cushing, C. E., Wayne Minshall, G., Newbold, J. D. (1993). Transport dynamics of fine particulate organic matter in 2 Idaho streams. Limnol. Oceanogr. 38: 1101-1115

Cushing, D. H. (1989). A difference in structure between ecosystems in strongly stratified waters and in those that are only weakly stratified. J. Plankton Res. 11: 1-13

d'Anglejan, B. F., Ingram, R. G. (1984). Near bottom variations of turbidity in the Saint-Lawrence Estuary. Estuar. coast. Shelf Sci. 19: 655-672

Dauvin, J.-C., Dodson, J. J. (1990). Relationship between feeding incidence and vertical and longitudinal distribution of rainbow smelt larvae (Osmerus mordax) in a turbid well-mixed estuary. Mar. Ecol. Prog. Ser. 60: 1-12

Dodson, J. J., Dauvin, J. C., Ingram, R. G., d'Anglejan, B. (1989). Abundance of larval rainbow smelt (Osmerus mor$d_{2 x}$ in relation to the maximum turbidity zone and associated macroplanktonic fauna of the middle St. Lawrence estuary. Estuaries 12: 66-81

Fichez, R., Jickells, T D., Edmunds, H. M. (1992). Algal blooms in high turbidity, a result of the conflicting consequences of turbulence on nutrient cycling in a shallow water estuary, Estuar. coast. Shelf Sci. 35: 577-592

Frenette, J.-J., Demers, S., Legendre, L., Bouié, M., Dodson, J. J. (1994). Mixing, stratification and the fate of primary production in an oligotrophic multibasin lake system (Québec, Canada). J. Plankton Res. 16: 1095-1115

Gobeil, C., Sundby, B., Silverberg, N. (1981). Factors influencing particulate matter geochemistry in the St Lawrence estuary turbidity maximum. Mar. Chem. 10 $123-140$

Kimmerer, W. (1992). An evaluation of existing data in the entrapment zone of the San Francisco Bay Estuary. Interagency Ecological Studies Program for the SacramentoSan Joaquin Estuary. Technical report 33. FS/BIO-IATR/ 92-33

Laprise, R., Dodson, J. J. (1989a). Ontogenetic changes in the longitudinal distribution of two species of larval fish in a turbid well-mixed estuary. J. Fish. Biol. (Suppl. A) 35: $39-47$

Laprise, R., Dodson, J. J. (1989b). Ontogeny and importance of tidal vertical migrations in the retention of larval smelt. Osmerus mordax in a well-mixed estuary. Mar. Ecol. Prog. Ser. 55: 101-111

Laprise, R., Dodson, J. J. (1990). The mechanism of retention of pelagic tomcod, Microgadus tomcod, larvae and juveniles in the well-mixed part of the St. Lawrence estuary. Environ. Biol. Fish. 29: 293-302

Laprise, R., Dodson, J. J. (1993). Nature of environmental variability experienced by benthic and pelagic animals in the St. Lawrence Estuary, Canada. Mar. Ecol. Prog. Ser. 94: $129-139$

Laprise, R, Dodson, J. J (1994). Environmental variability as 
a factor controlling spatial patterns in distribution and species diversity of zooplankton in the St. Lawrence Estuary. Mar. Ecol. Prog. Ser 107: 67-81.

Legendre, L., Le Fèvre, J. (1989). Hydrodynamic singularities as controls of recycled versus export production in oceans In: Berger, W. H., Smetacek, V. S., Wefer, G. (eds.) Productivity of the ocean: present and past. Wiley, New York p. $49-63$

Legendre, L., Legendre, P. (1984). Ecologie numérique, Vol. II, La structure des données écologiques, 2 nd edn Masson and Presses de l'Université du Québec, Québec

Lewis, W. M. Jr (1988). Primary production in the Orinoco River. Ecology 69: 679-692

Lovejoy, C., Vincent, W F., Frenette, J.-J., Dodson, J. J. (1993). Microbial gradients in a turbid estuary: application of a new method for protozoan community analysis. Limnol. Oceanogr. 38: 1295-1303

Lucotte, M., d'Anglejan, B. (1986). Seasonal control of the Saint-Lawrence maximum turbidity zone by tidal-flat sedimentation. Estuaries 9: 84-94

Meric, P. (1975). Circulation résiduelle dans l'estuaire moyen du Saint-Laurent et son influence sur les processus sédimentaires. Rapport no. CRE-75/03, Centre de recherches sur l'eau, Université Laval, Québec

Moon, C., Dunstan, W. M. (1990). Hydrodynamic trapping in the formation of the chlorophyll a peak in turbid, very low salinity waters of estuaries. J. Plankton Res. 12: 323-336

Painchaud, J., Lefaivre, D., Tremblay, G.-H., Therriault, J.-C. (1990). Analysis of the distribution of suspended particulate matter, bacteria, chlorophyll $a$ and $\mathrm{PO}_{4}$ in the upper St. Lawrence Estuary, using a two-dimensional box model In: Michaelis, W. (ed.) Coastal and estuarine studies. Springer-Verlag, Berlin, p. 59-6.5

Painchaud, J., Therriault, J.-C. (1989). Relationships between bacteria, phytoplankton and particulate organic carbon in the upper St. Lawrence Estuary. Mar. Ecol. Prog. Ser. 56: $301-311$

Painting, S. J., Moloney, C. L., Probyn, T. A., Tibbles, B. (1992). Microheterotrophic pathways in the Southern Benguela upwelling system. S. Afr. J. mar. Sci. 12: 527-543

This article was submitted to the editor
Postma, H. (1967). Sediment transport and sedimentation in the estuarine environment. In: Lauff, G. H. (ed.) Estuaries. Publication 83, American Association for the Advancement of Science, Washington, DC

Reynolds, C. S. (1984). The ecology of freshwater phytoplankton. University Press, Cambridge

Riegman, R., Kuipers, B. R., Noordeloos, A. A. M., Witte, H. G (1993). Size-differential control of phytoplankton and the structure of plankton communities. Neth. J. Sea Res. 31. $255-265$

Rogerson, A., Laybourn-Parry, J (1992a). The abundance of marine naked amoebae in the water column of the Clyde Estuary. Estuar. coast. Shelf Sci. 34: 187-196

Rogerson, A., Laybourn-Parry, J. (1992b). Aggregate dwelling protozooplankton communities in estuaries. Arch. Hydrobiol. 125: $411-422$

Schuchardt, B., Schirmer, M. (1991). Phytoplankton maxima in the tidal freshwater reaches of two coastal plain estuaries. Estuar. coast. Shelf Sci. 32: 187-206

Silverberg, N., Sundby, B. (1979). Observations in the turbidity maximum of the St. Lawrence estuary. Can. J. Earth Sci. 16: 939-950

Simenstad, C. A., Small, L. F., McIntire, C. D. (1990). Consumption processes and food web structure in the Columbia River Estuary. Prog. Oceanogr. 25: 271-297

Therriault, J.-C., Legendre, L., Demers, S. (1990). Oceanography and ecology of phytoplankton in the St. Lawrence Estuary. In: El-Sabh, M. I., Silverberg, N. (eds.) Oceanography of a large-scale estuarine system, the St. Lawrence. Springer-Verlag, Berlin, p. 269-281

Tsuji, T., Yanagita, T (1981). Improved fluorescent microscopy for measuring the standing stock of phytoplankton including fragile components. Mar. Biol. 64: 207-211

Vincent, W. F. (1992). The daily pattern of nitrogen uptake by phytoplankton in dynamic mixed layer environments. Hydrobiologia 238: 37-52

Vincent, W. F., Bertrand, N., Frenette, J.-J. (1994). Photoadaptation to intermittent light across the St. Lawrence Estuary freshwater-saltwater transition zone. Mar. Ecol. Prog. Ser. 110: $283-292$

Manuscript first received: March 31, 1994

Revised version accepted: January 23, 1995 